\title{
Identification of Human Remains Using mtDNA Sequence Analysis in Morocco
}

\author{
Hamid El Amri, Souad Boutayeb, Bouchra El Jennouni, Loubna Allam and Hicham El Ossmani \\ Royal Gendarmerie, Genetics Laboratory, Rabat, Avenue Ibn Sina 10100, Morocco
}

\begin{abstract}
Today, mtDNA typing is utilized primarily in cases in which the nuclear DNA is too degraded or cannot be recovered in sufficient quantities to be typed. Laboratory of Genetic of Royal Gendarmerie in Morocco is actively involved in using mtDNA for forensic identifications of human skeletal remains. Reproducible results were obtained for bones and teeth up to 52 years old. The bone and tooth samples were pulverized to fine powder, decalcified and DNA was extracted. 341-bp fragment from HVI (hypervariable region I) and 267-bp fragment from HVII (hypervariable region II) of the mtDNA control region were amplified. After sequencing of the PCR products, mitotypes were compared to the rCRS (revised Cambridge Reference Sequence) and a phylogenetic tree was built.
\end{abstract}

Key words: Forensic identification, mitochondrial DNA, human, skeletal remains.

\section{Introduction}

Sequence analysis of human mtDNA (mitochondrial DNA) has been demonstrated to be a valid and reliable tool for the genetic characterization of forensic biological specimens [1-3]. The human mtDNA is a $16569 \mathrm{np}$ (nucleotide pair) closed, circular molecule located within the cytoplasmic mitochondria. mtDNA has a very high mutation rate, approximately 10 -fold higher compared to nuclear DNA, probably as a result of poor repair mechanisms as well as a decreased proofreading efficiency of the mtDNA polymerase [4, 5].

In this paper, we report the sequencing of mtDNA of four skeletal remains belonging to four individuals missed up to 52 years old. The application of mtDNA sequence analysis for the identification of these remains was done for the first time in Genetic Laboratory of Royal Gendarmerie in Morocco.

\section{Materials and Methods}

\subsection{Decontamination Procedure}

Surface material was removed from the bones and

Corresponding author: Hicham El Ossmani, Ph.D., research field: anthropogenetics and biostatistics sciences. E-mail: helossmani@yahoo.fr. teeth by washing with diluted bleach then with distilled water. The cleaned bone fragments were treated with UV light at $1.0 \mathrm{~J} / \mathrm{cm} 2$ for $30 \mathrm{~min}$.

\subsection{Physical Grinding Procedure}

Samples were equally divided and powdered the next day using the same technique. The four samples were powdered in a cryogenic impact grinder (CertiPrep 6770 Freezer Mill, Spex/Mill, Spex, Metuchen, NJ) following the manufacturer's instructions.

\subsection{Demineralization Procedure}

Demineralization of dentin and bone powder was done by incubating each sample in $700 \mu \mathrm{L}$ to $1 \mathrm{~mL}$ of EDTA $0.5 \mathrm{M} \mathrm{pH} 8.5$ for $48 \mathrm{~h}$ at room temperature. Afterwards, EDTA solution was eliminated.

\subsection{DNA Extraction}

Physically powdered bone $(750 \mathrm{mg})$ was suspended in $1.6 \mathrm{~mL}$ of extraction buffer $(0.1 \mathrm{M}$ EDTA, $0.5 \%$ $\mathrm{N}$-laurylsarcosine-Na salt, $100 \mathrm{mg} / \mathrm{mL}$ proteinase $\mathrm{K}$ ), vortexed and incubated overnight at $37^{\circ} \mathrm{C}$ with continuous vertical rotation. After phase separation by centrifugation at room temperature at 12,000 r.p.m for $10 \mathrm{~min}, 250 \mu \mathrm{l}$ supernatant was transferred to a $1.5 \mathrm{~mL}$ 
Eppendorf tube and $3.5 \mu \mathrm{l} 1 \mu \mathrm{g} / \mu \mathrm{l}$ Dextran Blue (Sigma), $250 \mu 14 \mathrm{M}$ NH4-acetate and $500 \mu 196 \%$ EtOH were added and mixed by vortexing. Dextran Blue precipitates DNA and colors the pellet. The DNA was precipitated at $-70^{\circ} \mathrm{C}$ for 7 min and centrifuged at 14,000 r.p.m at $4^{\circ} \mathrm{C}$ for $15 \mathrm{~min}$. The remaining extract was stored at $-20^{\circ} \mathrm{C}$. This extract was purified with $D N A I Q^{T M}$ DNA isolation System (Promega).

\subsection{DNA Amplification and Sequensing}

Amplification primers were F15971 (5'-TTAACTCCACCATTAGCACC-3'), R16410 (5'-GAGGATGGTGGTCAAGGGAC-3') for HVI, and F15 (5'-CACCCTATTAACCACTCACG-3'), R448 (5'-TGAGATTAGTAGTATGGGAG-3') for HVII [6]. PCR was performed in a total volume of 25 $\mu \mathrm{l}$ consisting of 5-10 ng of template DNA, $2.5 \mu \mathrm{l} 10 \times$ PCR reaction buffer (Invitrogen, Karlsruhe, Germany), $1.5 \mathrm{mM} \mathrm{MgCl} 2,200 \mathrm{mM}$ each dNTP, 10 pmol each primer and $2 \mathrm{U}$ Platinum Taq DNA polymerase (Invitrogen). The amplification was carried out at $94{ }^{\circ} \mathrm{C}$ ( $2 \mathrm{~min}$ ) and then put through 38 reaction cycles: $94{ }^{\circ} \mathrm{C}$ for 30 s, $54{ }^{\circ} \mathrm{C}$ for 30 s and $72{ }^{\circ} \mathrm{C}$ for 30 s. The sequencing reaction was carried out in a final volume of $20 \mu \mathrm{l}$ containing $4 \mu \mathrm{l}$ BigDye Terminator RR Mix, 2 $\mu 15$ Big Dye Sequencing Buffer, 10 pmol primer and 4 $\mu 1$ PCR product. Cycling was performed (after a first denaturation step of $96{ }^{\circ} \mathrm{C}, 1 \mathrm{~min}$ ) for 25 cycles of $10 \mathrm{~s}$ at $96{ }^{\circ} \mathrm{C}, 5 \mathrm{~s}$ at $50{ }^{\circ} \mathrm{C}$ and $2 \mathrm{~min}$ at $60{ }^{\circ} \mathrm{C}$. Each template was sequenced in both forward and reverse directions using the amplification primers. Sequencing reaction products were purified by Sephadex G-50.

\subsection{Detection System}

Electrophoretic separation was carried out on an ABI Prism 3130xl Genetic Analyzer (Applied biosystems). All analyses were performed twice from independent bone samples.

\subsection{Quality Control}

All analyses were done in separate areas for the different steps including bone preparation, DNA extraction, PCR amplification and sequencing. Negative and positive controls were run in parallel.

\section{Results and Discussion}

\subsection{Case\#1}

By comparison of the mtDNA data from the bone sample to the revised Cambridge Reference Sequence, two transitions were found in HVI both C/T (Table 1). In HVII region seven transitions $(4 \mathrm{~A} / \mathrm{G}$ and $3 \mathrm{C} / \mathrm{T})$ and one insertion of a cytosine were found (Table 2).

\subsection{Case\#2}

In this case, the mtDNA data from the bone sample to the revised Cambridge Reference Sequence revealed, also two transitions (both $\mathrm{C} / \mathrm{T}$ ) in HVI region (Table 1). Four transitions $(2 \mathrm{~A} / \mathrm{G}$ and $2 \mathrm{C} / \mathrm{T})$ and one insertion of a cytosine were found in HVII sequence (Table 2).

\subsection{Case\#3:}

This is only case that revealed one transversion A/C in HVI when compared to the revised Cambridge Reference Sequence. In this hypervariable region we found, also, three transitions (2C/T and $1 \mathrm{~A} / \mathrm{G})$ (Table 1). In HVII region, we found two insertions of a cytosine and two transitions both $\mathrm{A} / \mathrm{G}$ (Table 2).

\subsection{Case\#4:}

Two transitions were found in both HVI and HVII (respectively $2 \mathrm{C} / \mathrm{T}$ and $2 \mathrm{~A} / \mathrm{G}$ ) when compared to the revised Cambridge Reference Sequence (Tables 1 and 2). Two insertions of a cytosine were also found in HVII region.

\section{Global Analysis}

To search for compatibilities among mtDNA sequences, these ones were analyzed three times (the revised Cambridge Reference Sequence with) in the dnacomp program of phylip 3.67 software [7].

Sequences of three cases (\#1, \#2 and \#4) showed the shorter time of divergence from the revised Cambridge 
Table 1 Observed differences between HVI sequences of the four cases and the one of revised Cambridge reference sequence.

\begin{tabular}{llllllllllll}
\hline Sites & 16069 & 16124 & 16126 & 16172 & 16219 & 16223 & 16224 & 16258 & 16278 & 16311 \\
\hline rCRS & C & T & T & T & A & C & T & A & C & T \\
Case\#1 & T & T & C & T & A & C & T & A & C & T \\
Case\#2 & C & C & T & T & A & T & T & A & C & T \\
Case\#3 & C & T & T & C & G & C & T & C & T & T \\
Case\#4 & C & T & T & T & A & C & C & A & C & C \\
\hline
\end{tabular}

Table 2 Observed differences between HVII sequences of the four cases and the one of revised Cambridge reference sequence.

\begin{tabular}{|c|c|c|c|c|c|c|c|c|c|c|c|}
\hline Sites & 73 & 150 & 152 & 185 & 195 & 228 & 263 & 265 & 295 & 309.1 & 315.1 \\
\hline rCRS & $\mathrm{A}$ & $\mathrm{C}$ & $\mathrm{T}$ & $\mathrm{G}$ & $\mathrm{T}$ & $\mathrm{G}$ & $\mathrm{A}$ & $\mathrm{T}$ & $\mathrm{C}$ & $-^{\mathrm{a}}$ & $-^{a}$ \\
\hline Case\#1 & G & $\mathrm{C}$ & $\mathrm{T}$ & $\mathrm{A}$ & $\mathrm{C}$ & A & $\mathrm{G}$ & $\mathrm{C}$ & $\mathrm{T}$ & $-{ }^{\mathrm{a}}$ & $\mathrm{C}$ \\
\hline Case\#2 & $\mathrm{G}$ & $\mathrm{T}$ & $\mathrm{C}$ & $\mathrm{G}$ & $\mathrm{T}$ & G & G & $\mathrm{T}$ & $\mathrm{C}$ & $\mathrm{C}$ & $-{ }^{a}$ \\
\hline Case\#3 & $\mathrm{G}$ & $\mathrm{C}$ & $\mathrm{T}$ & G & $\mathrm{T}$ & G & G & $\mathrm{T}$ & $\mathrm{C}$ & $\mathrm{C}$ & $\mathrm{C}$ \\
\hline Case\#4 & $\mathrm{G}$ & $\mathrm{C}$ & $\mathrm{T}$ & $\mathrm{G}$ & $\mathrm{T}$ & $\mathrm{G}$ & $\mathrm{G}$ & $\mathrm{T}$ & $\mathrm{C}$ & $\mathrm{C}$ & $\mathrm{C}$ \\
\hline
\end{tabular}

${ }^{\mathrm{a}}$ : Single base insertion.

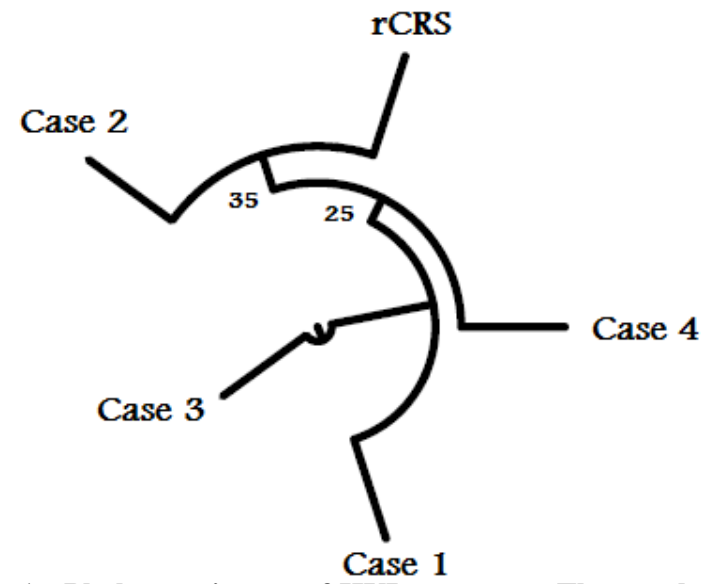

Fig. 1 Phylogenetic tree of HVI sequences. The number of each branch is the bootstrap value obtained for 1000 replicates.

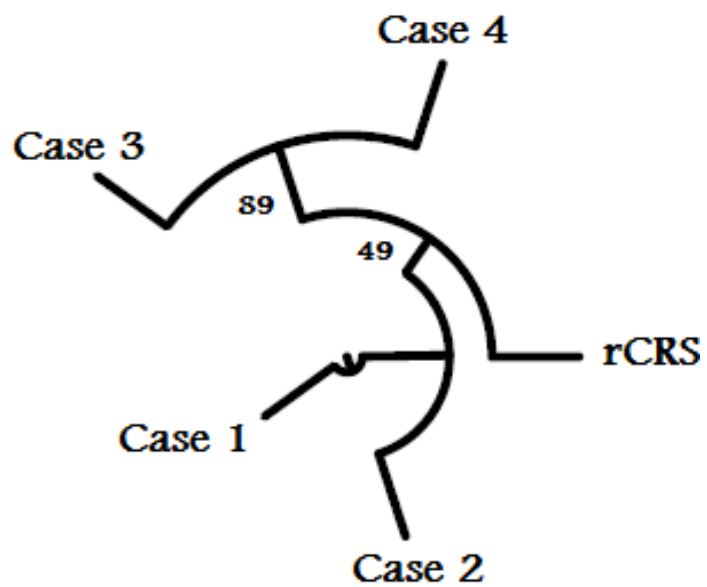

Fig. 2 Phylogenetic tree of HVII sequences. The number of each branch is the bootstrap value obtained for 1000 replicates.
Reference Sequence in opposite of the fourth case\#3 sequence which is the most distant from the reference sequence and from the three other cases sequences as illustrated in the phylogenetic tree (Fig. 1).

The second analysis revealed a different schema of compatibilities among sequences. According to the revised Cambridge Reference Sequence, case\#1 seems to have the most distant sequence, while sequences of case\#3 and case\#4 are the closest ones. Case\#1 sequence is, also, the most distant from the three other cases sequences which are relatively closer from each other (Fig. 2).

\section{References}

[1] Allen, M., Engstrom, A. S., Myers, S., Handt, O., Saldeen, T., von Haeseler, A., Pääbo, S., and Gyllensten, U. 1998. "Mitochondrial DNA Sequencing of Shed Hairs and Saliva on Robbery Caps: Sensitivity and Matching Probabilities." J. Forens. Sci. 43 (4): 453-64.

[2] Boles, T. C., Snow, C. C., and Stover, E. 1995. "Forensic DNA Testing on Skeletal Remains from Mass Graves: A Pilot Project in Guatemala.” J. Forens. Sci. 40 (3): 349-55.

[3] Gill, P., Ivanov, P. L., Kimpton, C., Piercy, R., Benson, N., Tully, G., Evett, I., Hagelberg, E., and Suullivan, K. 1994. "Identification of the Remains of the Romanov Family by DNA Analysis." Nat. Genet. 6 (2): 130-5.

[4] Budowle, B., Wilson, M. R., DiZinno, J. A., Stauffer, C., Fasano, M., Holland, M., and Monson, K. 1999. "Mitochondrial DNA Regions HVI and HVII Population 
Data." Forensic. Sci. Int. 103 (1): 23-35.

[5] Butler, J. M. 2005. Forensic DNA Typing, 2nd edition. New York: Elsevier Academic Press.

[6] Holland, M. M., Fisher, D. L., Roby, R. K., Ruderman, J., Bryson, C. and Weedn, V. W. 1995 "Mitochondrial DNA
Sequence Analysis of Human Remains." Crime Lab Digest 22: 109-15.

[7] Felsenstein, J. 2007. Phylogeny Inference Package (PHYLIP) Version 3.67. Department of Genetics, University of Washington, Seattle. USA. 